p.206 㲘定 ・評価

411. サッカーのゲーム分析 (3)

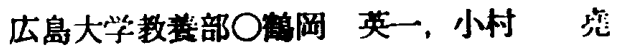
広島大学教有学部付辰高校福 原黎三

$<$ 目 的 $>$

サッカーのゲームにおいてて相手随占有時間」が時间 経過にとあなってどのように变偊するかを考宗する．今 回は変動の㸡期性について湌討する。

\section{<方 法>}

(1)モデルとしたゲーム： イキシコ・オリンピック・ アジア地区予選 10ゲーム. 忩島県高等学校公式試合 12 ゲーム.

(2)データの処理：各ゲームについて释通時間 2 分ご との「湘手陣占有時間」のイン・ブレイ時間に対する百 分桨を算出して原系列とした。舟列の項数は、オリンビ ック予選では 45，高栈のゲームでは30であった。この 原系列の周期性の有無について、シュスターの夙期分析 㳎によって解析をおこなった。

\section{$<$ 結 果>}

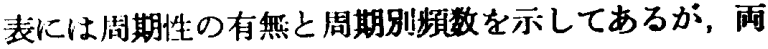
グループとすに，1/2 以上のゲームに有意な周期がみら
れた $(\mathbf{P}<0.05)$ 。「相手陣占有時間」の変䖝における周 期性の有焦が，ゲーム内容の如何なる要因と関連してい るかは，晛段階では不明である。また高期性が琹められて るるのについて，その夙期の長さについてみると，高校 クループは比效的広筙囲にハラッッいているのに対して，

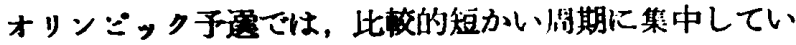
ろ.これらの原因む現段階では不明である。

しかし，ダーム全体の推移を考えたばあい，その胳期 性を俗討する可能性が見出された．そして「相手陣占有 時間」の時間经違にとるなら変動をフーリエ級数によっ て表睍し5る見通しをえたので，これまでに蒐集したデ 一タにこれらを当てはめて考察したい。

相手陣占有時間の周期

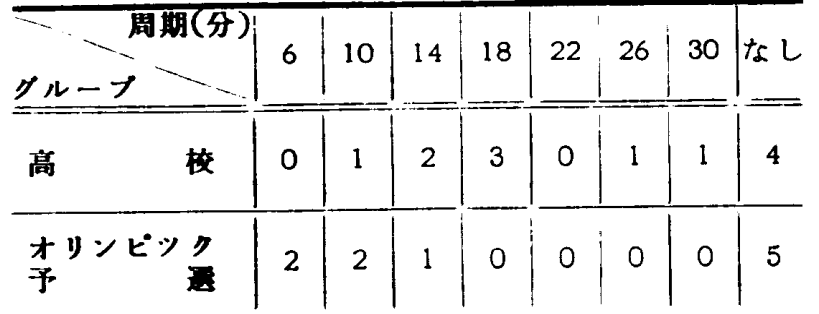

412. サッカーのゲームに朝する突的不宽

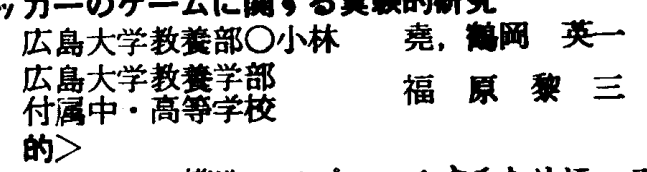

$<$ 目 的 $>$

サッカーのゲームの模造へアプローチするために、ス キル使用の制限を加えた実险的立場面を設定し，ゲーム 内容の変動を考察する. 今回は，キーピング使用に制限 を加えたのについて報告する。

〈方 法〉

(1)湘定垻目・方法…「サッカーのゲーム分析」第 1 報 のとおり. (2)潰対象…高校ティームKよる12 ゲーム. (3)央験条件…試合時間 30 分〜30 分のゲームにおいて, 前半は普通のゲーム，後半は，次の様な条件を与えてゲ 一ムをおこなわせた。「自分のところにきたボールは， 最初に，キーピンク，または，ヘッデイングで如理す る」この条件に遠反した場合は，相手方に間接フリーキ
ックを与えることにした。

〈结 具〉

(1) 全体のスキル使用数は，策件を与えても变らなか つた. しかし，大部分の各スキルの使用数には，かなり の変動がみられた。

(2) 全スキルの有効率は采件をを与えだあい，高まつ た，各スキル別の有好蛙をみると，キッキングの有効率 の增加が，取る增著であった。

(3) 各定員目閶において，有意な相閶があったも のは，㭔件をつけたばあい，增加していることが示さ れた.

(4) シューテイング数とその得点をみた時，条件をつ けたばあいの方が，その有効率は低かった。

(6) シューティンクに至る連けい[四数とその覑度につ いて，音通ゲームと条件つきのゲームを㭘討した結果， 两者の间飞差注められなかった。

スキルの使用数・有效率・使用比标の此校

\begin{tabular}{|c|c|c|c|c|c|c|c|c|c|}
\hline 項 目 & 使用数 & $\left(\begin{array}{l}1 \% \\
\text { 時間 } 1\end{array}\right.$ & $\begin{array}{l}\text { プレイ } \\
\text { 分当り }\end{array}$ & 有 & 炀 & 弗 & & 用 比 & \\
\hline スキル 件 & (1)なし & ஒあり & F(2)-(1) & (1) & (3) & (2) - (1) & (1) & (3) & (2) - (1) \\
\hline 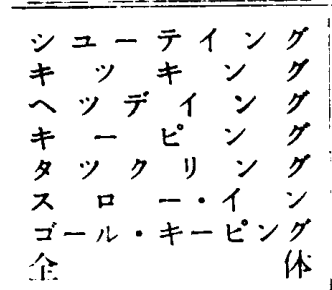 & $\begin{array}{r}0.32 \\
6.81 \\
0.94 \\
4.76 \\
0.84 \\
0.66 \\
0.56 \\
14.89\end{array}$ & $\begin{array}{r}0.39 \\
5.52 \\
0.67 \\
6.05 \\
1.36 \\
0.43 \\
0.55 \\
14.96\end{array}$ & $\begin{array}{c}0.07 \\
-1.29^{* *} \\
-0.27^{* * *} \\
1.29^{* *} \\
0.52^{* *} \\
-0.23^{* *} \\
-0.01 \\
0.09\end{array}$ & $\begin{array}{l}22.1 \\
51.5 \\
46.8 \\
69.3 \\
50.8 \\
77.9 \\
83.9 \\
58.5\end{array}$ & $\begin{array}{l}13.1 \\
55.9 \\
52.0 \\
69.9 \\
49.4 \\
79.8 \\
83.1 \\
61.2\end{array}$ & $\begin{array}{c}-9.0 \\
4.4^{*} \\
9.6^{*} \\
0.6 \\
-1.4 \\
1.9 \\
-0.8 \\
2.7^{* *}\end{array}$ & $\begin{array}{r}2.2 \\
45.7 \\
6.3 \\
32.0 \\
5.7 \\
4.4 \\
3.8 \\
100.0\end{array}$ & $\begin{array}{r}2.6 \\
36.9 \\
4.5 \\
40.4 \\
9.1 \\
2.9 \\
3.7 \\
100.0\end{array}$ & $\begin{aligned} & 0.4 \\
- & 8.4^{* * *} \\
- & 1.8^{* * *} \\
& 8.4^{* * *} \\
& 3.4^{* *} \\
- & 1.5^{* *} \\
- & 0.1\end{aligned}$ \\
\hline
\end{tabular}

